\title{
Evaluation of Cucumber Hybrids/Lines for Yield and Quality under Polyhouse
}

\author{
K. Gangadhara ${ }^{1 *}$, Raj Kumar ${ }^{2}$, R. Selvakumar ${ }^{3}$, V.V. Apparao ${ }^{1}$ and L.P. Yadav ${ }^{1}$ \\ ${ }^{1}$ ICAR-CIAH, RS-CHES, Vejalpur, Godhra, Gujarat, India \\ ${ }^{2}$ SMS (Horticulture), KVK, Panchamahal, Gujarat, India \\ ${ }^{3}$ ICAR-Central Institute of Temperate Horticulture, KD Farm, Old Air Field, Rangreth-190 \\ 007, Srinagar, Jammu and Kashmir, India \\ *Corresponding author
}

\section{A B S T R A C T}

Keywords

Cucumber

(Cucumis sativus

L.), Gynoecious

parthenocarpic

Article Info

Accepted:

12 May 2019

Available Online:

10 June 2019
Fifteen gynoecious parthenocarpic hybrids hybrids/lines of cucumber (Cucumis sativus L.) were evaluated under polyhouse (fifty percent shade/naturally ventilated) conditions for yield and quality. The genotypic and phenotypic coefficient of variations were highest for nodal position of first female flower, number fruits, fruit weight and fruit yield per plant which indicates maximum variability is existing in the genotypes. High genetic advance as per cent mean was observed for most of the characters, indicating that these characters are controlled by additive gene action. Correlation studies revealed that at both phenotypic and genotypic level highly significant and positive association of fruit yield per plant with number of fruits per plant and negative association with days to first female flower, nodal position of first female flower and days to fifty percent flowering indicating the possibility of simultaneous selection for these traits to improve the fruit yield. maximum positive direct effects towards fruit yield per plant was contributed by days to fifty percent flowering, number of fruits per plant and fruit weight were the most influencing factors.

\section{Introduction}

Cucumber (Cucumis sativus L., $2 \mathrm{n}=2 \mathrm{x}=14$ ), an economically important member of the gourd family, Cucumber is one of the most preferred vegetables grown under protected conditions in the world. Its demand is throughout the year because of its popular use in salad dish, sandwich, pizza preparations etc. It is believed to be originated in India (De Candolle). India is endowed with enormous variability and genetic divergence for cucumber germplams throughout the country. However, several unique indigenous germplasm that could potentially enhance cucumber productivity and nutritional quality, have not yet been widely utilized in crop improvement programmes due to lack of relevant information. So, there is a great need of screening cucumber germplasm to identify elite genotypes with improved quality and higher yield so that they may be utilized either directly as a selection or as a parent in hybridization programme. Cucumber, being a 
high value low volume crop, its exploitation on commercial scale in naturally ventilated polyhouse can improve productivity and generate good income to the growers. These technologies are highly suitable for increasing the socioeconomic status of small farmers through high profitability. For any effective selection programme, the information on the nature and magnitude of variability present in the genotypes, heritability and genetic advance are important. A study of correlation between different quantitative characters provides an idea of association.

It could be effectively exploited to formulate selection strategies for improving yield and quality. The path coefficient technique helps in estimating direct and indirect contribution of various components in building up the correlation towards yield. Hence, the present investigation was carried out to analyze variability and association for yield and quality parameters under polyhouse.

\section{Materials and Methods}

The experiment entitled "Evaluation of cucumber hybrids/lines for quality and yield in polyhouse" was conducted at division of vegetable crops, Indian Institute of Horticultural Research, Hessaraghatta, Bengalulru during winter season. The experimental material comprised of 15 accessions of cucumber collected from different parts of the country. The details of genotypes used for the experiment is given in Table 1. The experiment was laid out in a randomized block design with 15 treatments and three replications. The seed sowing of all the genotypes was carried out in the pro trays to get a healthy uniform seedlings. Thirty days old seedlings were transplanted into the poly house with fifty per cent shade net (naturally ventilated polyhouse). Inside the polyhouse raised beds were made and planting was done at a spacing of $60 \times 100$ $\mathrm{cm}$. The raised beds were covered with black polythene mulch and whole polyhouse was irrigated through drip. The crop received timely management practices as per package of practices recommendations of Indian Institute of Horticultural Research. Growth and yield characters like days to first female flower, nodal position to first female flower, days to $50 \%$ flowering, fruit length $(\mathrm{cm})$, fruit weight $(\mathrm{g})$, fruit girth $(\mathrm{cm})$, number of fruits per plant, plant height $(\mathrm{cm})$ and fruit yield per plant $(\mathrm{kg})$. The quality parameters like colour of fruit, spines on fruit surface, bitter taste of fruit, hallow or spliting and ribs on fruit surface. The variance components and coefficients of variation were computed as per Burten (1952). The heritability in broad sense and expected genetic advance were determined by using the formula given by Johnson et al., (1955). The correlation coefficient among all possible character combinations at phenotypic and genotypic level were estimated employing formula given by Al-Jibouri et al., (1958). Path coefficient analysis suggested by Wright (1921) Dewey and Lu (1959).

\section{Results and Discussion}

With a view to understand the extent to which the observed variations are due to genetic factors, the range, mean, PCV, GCV, heritability $\left(\mathrm{h}^{2}\right)$, genetic advance (GA) and genetic advance as per cent of mean (GAM) (Table 2). The data revealed the existence of large amount of variability to most of the characters. The estimates of GCV and PCV for days to first female flower were moderate (14.12 and 14.17, respectively). High heritability (99.26\%) was observed along with high genetic advance as per cent of mean (28.98\%) and moderate GA $(12.93 \%)$ for the trait was found. The estimates of GCV and PCV for nodal position to female flower were high (48.44 and 51.04, respectively). High heritability (90.07\%) was observed along 
with high genetic advance as per cent of mean $(94.71 \%)$ and low GA (4.95\%).Days to fifty percent flowers were had low GCV and PCV (8.32 and 8.45, respectively) but High heritability (96.87 \%) was observed along with moderate genetic advance as per cent of mean (16.86\%) and low GA (9.83\%). Similar results were reported by Das et al., (2003), Munshi et al., (2007), Hanchinamani et al., (2008), Yogesh et al., (2009) and Kumar et al., (2013).

High GCV and PCV for number of fruits (40.99 and 41.24, respectively) were observed. High heritability $(98.98 \%)$ was observed along with high genetic advance as per cent of mean $(83.92 \%)$ and high GA $(24.52 \%)$. The estimates of GCV and PCV for fruit weight were high (26.40 and 27.39, respectively). High heritability $(92.88 \%)$ was observed along with high genetic advance as per cent of mean $(52.41 \%)$ and high GA (114.60). The estimates of GCV and PCV for fruit length were moderate (16.91 and 17.50, respectively). High heritability $(93.37 \%)$ was observed along with high genetic advance as per cent of mean (33.66\%) and low GA (6.11) for the trait was found. The estimates of GCV and PCV for fruit girth were low (5.86 and 6.72 , respectively). High heritability $(76.05 \%)$ was observed along with moderate genetic advance as per cent of mean $(10.52 \%)$ and low GA (1.49) for the trait was found. Moderate GCV and PCV for plant height (11.73 and 12.15, respectively) were observed. High heritability $(93.39 \%)$ was observed along with high genetic advance as per cent of mean $(23.38 \%)$ and high GA (61.41) for the trait was found. The estimates of GCV and PCV for fruit yield per plant were high (38.22 and 38.93, respectively). High heritability (96.37 \%) was observed along with high genetic advance as per cent of mean $(77.28 \%)$ and low GA (4.75) for the trait was found. Similar results were reported by Das et al., (2003), Munshi et al., (2007),
Hanchinamani et al., (2008), Yogesh et al., (2009), Kumar et al., (2013), Verma et al., (2003), Kumar et al., (2008), Joshi et al., (1981), devmore et al., (2010), Bisht et al., (2010), Eifediyi and Remison (2009), Rakhi and Rajmony (2005) and Singh(2007). The characters which showing high PCV with equally high GCV, high heritability coupled with high genetic advance which indicates maximum variability is existing in the genotypes for these characters and offers good scope for improvement by simple selection through these characters. High heritability coupled with high genetic advance which indicating that these characters are less influenced by environmental factors and are under the control of additive gene effect and selection for improvement of such characters would be rewarding.

The phenotypic and genotypic correlation for different characters is presented in Tables 3 and 4 respectively. In the present study, Fruit yield per plant showed significant positive correlation with number of fruits per plant (0.819), plant height (0.302) and significant negative correlation with days to fifty percent flowering (-0.682), nodal position of first female flower (-0.652) and days to first female flower (-0.373). Nodal position of first female flower showed significant positive correlation with days to first female flower (0.659) whereas days to fifty percent flowering showed significant positive correlation with days to first female flower (0.515) and nodal position of first female flower (0.474).similar results were reported by Verma (2003), Kumar et al., (2008), Munshi et al., (2007), Hanchinamani et al., (2008), Kumar et al., (2013), Soleimani et al., (2009), Singh et al., (2002). Number of fruits per plant showed significant negative correlation with days to first female flower (0.483 ), nodal position of first female flower (0.788 ) and days to fifty percent flowering (0.503). Fruit weight showed positive 
correlation with days to first female flower $(0.238)$ and nodal position of first female flower (0.265) whereas significant negative correlation was found with number of fruits per plants (-0.356). Fruit length showed significant positive correlation with fruit weight (0.502) whereas only positive correlation with days to first female flower $(0.290)$ and nodal position of first female flower (0.282). It also showed negative correlation with number of fruits (-0.136) whereas fruit girth showed significant positive correlation with fruit weight (0.751) and it has shown significant negative correlation days to fifty percent flowering (-0.394). Plant height showed significant positive correlation with number of fruits (0.403) and significant negative correlation was found with fruit girth (-0.295). Similar results were reported by Bisht et al., (2010), Sharma et al., (2010), Badgujar and More (2004) and Gulam ud din et al., (2006), Eifediyi and Remison (2009), Shaw et al., (2000), Dijkhuizen and Staub (2002), Singh et al., (2002), Das et al., (2003), Verma (2003), Kumar et al., (2008), Munshi et al., (2007), Hanchinamani et al., (2008), Kumar et al., (2013), Soleimani et al., (2009), Singh et al., (2002).

Table.1 Name of the genotypes and quality parameters in cucumber

\begin{tabular}{|c|c|c|c|c|c|c|}
\hline $\begin{array}{l}\text { S. } \\
\text { No }\end{array}$ & Genotype name & Fruit colour & $\begin{array}{l}\text { Spines on fruit } \\
\text { surface }\end{array}$ & Bitterness & Hallow & Ribs \\
\hline 1 & Polyhouse mix & Light green & Present & Absent & Absent & Absent \\
\hline 2 & Parthenocarpic-2 & Dark green & Present & Absent & Present & Absent \\
\hline 3 & Parthenocarpic & Dark green & Absent & Absent & Absent & Absent \\
\hline 4 & Pcu-5039 & $\begin{array}{l}\text { Green with white } \\
\text { stripes }\end{array}$ & Present & Absent & Absent & Present \\
\hline 5 & US-646 & $\begin{array}{l}\text { Light green with } \\
\text { white stripes }\end{array}$ & Present & Absent & Present & Absent \\
\hline 6 & Pcu-2 & $\begin{array}{l}\text { Green with white } \\
\text { stripes }\end{array}$ & Present & Absent & Absent & Present \\
\hline 7 & $\begin{array}{l}\text { Pcu-1 } \\
\text { SM12735 }\end{array}$ & $\begin{array}{l}\text { Green with white } \\
\text { stripes }\end{array}$ & Present & Absent & Present & Present \\
\hline 8 & Sabari & $\begin{array}{l}\text { Light green with } \\
\text { white stripes }\end{array}$ & Present & Absent & Present & Present \\
\hline 9 & Heera & $\begin{array}{l}\text { Green with white } \\
\text { stripes }\end{array}$ & Present & Absent & Present & Present \\
\hline 10 & KAU Thrissur & $\begin{array}{l}\text { Green with white } \\
\text { stripes }\end{array}$ & Absent & Absent & Absent & Absent \\
\hline 11 & US-640 & $\begin{array}{l}\text { Light green with } \\
\text { white stripes }\end{array}$ & Present & Absent & Present & Absent \\
\hline 12 & Valley Star & Dark green & Absent & Absent & Absent & Absent \\
\hline 13 & Silyon & Dark green & Absent & Absent & Absent & Absent \\
\hline 14 & Pune collection & Dark green & Absent & Absent & Absent & Absent \\
\hline 15 & Multi Star & Dark green & Absent & Absent & Absent & Absent \\
\hline
\end{tabular}


Table.2 Estimates of genetic parameters of variability in cucumber

\begin{tabular}{|c|c|c|c|c|c|c|c|c|}
\hline \multirow[t]{2}{*}{ Character } & \multicolumn{2}{|c|}{ Range } & \multirow[b]{2}{*}{ Mean } & \multirow[b]{2}{*}{ GCV } & \multirow[b]{2}{*}{ PCV } & \multirow[b]{2}{*}{ Heritability } & \multirow{2}{*}{$\begin{array}{l}\text { Genetic } \\
\text { advance at } 5 \%\end{array}$} & \multirow{2}{*}{$\begin{array}{l}\text { Genetic } \\
\text { advance as \% } \\
\text { mean }\end{array}$} \\
\hline & Min. & Max. & & & & & & \\
\hline Days to first female flower & 36.20 & 54.53 & 44.61 & 14.12 & 14.17 & 99.26 & 12.93 & 28.98 \\
\hline $\begin{array}{l}\text { Nodal position to First } \\
\text { Female flower }\end{array}$ & 1.83 & 9.50 & 5.22 & 48.44 & 51.04 & 90.07 & 4.95 & 94.71 \\
\hline Days to $50 \%$ flowering & 49.27 & 69.77 & 58.26 & 8.32 & 8.45 & 96.87 & 9.83 & 16.86 \\
\hline No. of fruits per plant & 16.87 & 49.73 & 29.22 & 40.99 & 41.24 & 98.78 & 24.52 & 83.92 \\
\hline Fruit weight (g) & 121.0 & 342.7 & 218.65 & 26.40 & 27.39 & 92.88 & 114.60 & 52.41 \\
\hline Fruit length $(\mathrm{cm})$ & 13.02 & 23.37 & 18.15 & 16.91 & 17.50 & 93.37 & 6.11 & 33.66 \\
\hline Fruit girth $(\mathbf{c m})$ & 12.83 & 16.24 & 14.14 & 5.86 & 6.72 & 76.05 & 1.49 & 10.52 \\
\hline Plant height (cm) & 183.13 & 303.17 & 262.66 & 11.73 & 12.15 & 93.39 & 61.41 & 23.38 \\
\hline Fruit yield per plant (kg) & 2.78 & 9.81 & 6.15 & 38.22 & 38.93 & 96.37 & 4.75 & 77.28 \\
\hline
\end{tabular}

GCV- Genotypic co-efficient of variation; PCV- Phenotypic co-efficient of variation

Table.3 Phenotypic coefficient of correlation of different characters in cucumber

\begin{tabular}{|c|c|c|c|c|c|c|c|c|c|}
\hline & $\mathbf{1}$ & $\mathbf{2}$ & $\mathbf{3}$ & $\mathbf{4}$ & $\mathbf{5}$ & $\mathbf{6}$ & $\mathbf{7}$ & $\mathbf{8}$ & $\mathbf{9}$ \\
\hline $\mathbf{1}$ & 1 & $0.659^{* *}$ & $0.515^{* *}$ & $-0.483^{* *}$ & 0.238 & 0.290 & 0.046 & -0.163 & $-0.373^{*}$ \\
\hline $\mathbf{2}$ & & 1 & $0.474^{* *}$ & $-0.788^{* *}$ & 0.265 & 0.282 & 0.090 & -0.052 & $-0.652^{* *}$ \\
\hline $\mathbf{3}$ & & & 1 & $-0.503^{* *}$ & -0.269 & 0.028 & $-0.394^{* *}$ & -0.176 & $-0.682^{* *}$ \\
\hline $\mathbf{4}$ & & & & 1 & $-0.356^{*}$ & -0.136 & -0.155 & $0.403^{* *}$ & $0.819^{* *}$ \\
\hline $\mathbf{5}$ & & & & & 1 & $0.502^{* *}$ & $0.751^{* *}$ & -0.278 & 0.212 \\
\hline $\mathbf{6}$ & & & & & & 1 & 0.115 & 0.007 & 0.215 \\
\hline $\mathbf{7}$ & & & & & & & 1 & $-0.295^{*}$ & 0.229 \\
\hline $\mathbf{8}$ & & & & & & & & 1 & $0.302^{*}$ \\
\hline $\mathbf{9}$ & & & & & & & & & 1 \\
\hline
\end{tabular}

Table.4 Genotypic coefficient of correlation of different characters in cucumber

\begin{tabular}{|c|c|c|c|c|c|c|c|c|c|}
\hline & $\mathbf{1}$ & $\mathbf{2}$ & $\mathbf{3}$ & $\mathbf{4}$ & $\mathbf{5}$ & $\mathbf{6}$ & $\mathbf{7}$ & $\mathbf{8}$ & $\mathbf{9}$ \\
\hline $\mathbf{1}$ & 1 & $0.700^{* *}$ & $0.527^{* *}$ & $-0.487^{* *}$ & 0.249 & $0.305^{*}$ & 0.038 & -0.164 & $-0.379^{*}$ \\
\hline $\mathbf{2}$ & & 1 & $0.510^{* *}$ & $-0.833^{* *}$ & 0.251 & 0.291 & 0.063 & -0.087 & $-0.716^{* *}$ \\
\hline $\mathbf{3}$ & & & 1 & $-0.519^{* *}$ & -0.277 & 0.034 & $-0.453^{* *}$ & -0.195 & $-0.707^{* *}$ \\
\hline $\mathbf{4}$ & & & & 1 & $-0.373^{*}$ & -0.139 & -0.163 & $0.412^{* *}$ & $0.825^{* *}$ \\
\hline $\mathbf{5}$ & & & & & 1 & $0.523^{* *}$ & $0.856^{* *}$ & $-0.312^{*}$ & 0.186 \\
\hline $\mathbf{6}$ & & & & & & 1 & 0.155 & 0.003 & 0.218 \\
\hline $\mathbf{7}$ & & & & & & & 1 & $-0.361^{*}$ & 0.278 \\
\hline $\mathbf{8}$ & & & & & & & & 1 & $0.303^{*}$ \\
\hline $\mathbf{9}$ & & & & & & & & & 1 \\
\hline
\end{tabular}

1. Days to first female flower

2. Nodal position to first female flower

3. Days to $50 \%$ flowering

4. Number of fruits per plant

5. $\quad$ Fruit weight $(\mathrm{g})$

6. $\quad$ Fruit length $(\mathrm{cm})$

7. $\quad$ Fruit girth $(\mathrm{cm})$

8. Plant height $(\mathrm{cm})$

9. $\quad$ Fruit yield per plant $(\mathrm{kg})$

** Significant at $1 \%$ level of significance; * Significant at $5 \%$ level of significance 
Table.5 Estimation of direct and indirect effects of different traits in cucumber

\begin{tabular}{|c|c|c|c|c|c|c|c|c|c|}
\hline Traits & 1 & 2 & 3 & 4 & 5 & 6 & 7 & 8 & rG \\
\hline 1 & -0.3557 & 0.5077 & 0.0537 & -0.8852 & 0.4039 & -0.10774 & -0.0310 & 0.0347 & $-0.379 *$ \\
\hline 2 & -0.2489 & 0.7253 & 0.0519 & -1.5147 & 0.4071 & -0.1027 & -0.052 & 0.0183 & $-0.716^{* * *}$ \\
\hline 3 & -0.1873 & 0.3697 & 0.1019 & -0.9427 & -0.4493 & -0.0118 & 0.3714 & 0.0413 & $-0.707^{* *}$ \\
\hline 4 & 0.1732 & -0.6044 & -0.0528 & 0.8176 & -0.6047 & 0.0493 & 0.1339 & -0.0873 & $0.825^{* *}$ \\
\hline 5 & -0.0887 & 0.1823 & -0.0282 & -0.6786 & 0.6198 & -0.1848 & -0.7020 & 0.0660 & 0.186 \\
\hline 6 & -0.1084 & 0.2108 & 0.0034 & -0.2535 & 0.8468 & -0.3535 & -0.1270 & -0.00056 & 0.218 \\
\hline 7 & -0.0134 & 0.046 & -0.0461 & -0.2968 & 1.3867 & -0.0547 & -0.8201 & 0.0766 & 0.278 \\
\hline 8 & 0.0584 & -0.0628 & -0.0198 & 0.7493 & -0.5052 & -0.0009 & 0.2964 & -0.2119 & $0.303^{*}$ \\
\hline
\end{tabular}

rG. Genotypic correlation with fruit yield per plant

** Significant at $1 \%$ level of significance

* Significant at 5\% level of significance

1. Days to first female flower

2. Nodal position to first female flower

3. Days to $50 \%$ flowering

4. Number of fruits per plant

5. $\quad$ Fruit weight $(\mathrm{g})$

6. $\quad$ Fruit length $(\mathrm{cm})$

7. $\quad$ Fruit girth $(\mathrm{cm})$

8. Plant height $(\mathrm{cm})$

In genotypic correlation coefficients, fruit yield per plant showed significant positive correlation with number of fruits per plant (0.825), plant height (0.303) and significant negative correlation with days to fifty percent flowering (-0.707), nodal position of first female flower (-0.716) and days to first female flower (-0.379). Nodal position of first female flower showed significant positive correlation with days to first female flower $(0.700)$ whereas days to fifty percent flowering showed significant positive correlation with days to first female flower (0.527) and nodal position of first female flower (0.510). Similar results were reported by Verma (2003), Kumar et al., (2008), Munshi et al., (2007), Hanchinamani et al., (2008), Soleimani et al., (2009), Singh et al., (2002), Rakhi and Rajmony (2005), Kumar et al., (2013) and Singh (2007). Number of fruits per plant showed significant negative correlation with days to first female flower (0.487), nodal position of first female flower ($0.833)$ and days to fifty percent flowering (0.519). Fruits weight showed positive correlation with days to first female flower
(0.249) and nodal position of first female flower (0.251) whereas significant negative correlation was found with number of fruits per plants (-0.373).Fruit length showed significant positive correlation with fruit weight $(0.523)$ and days to first female flower (0.305). It also showed negative correlation with number of fruits $(-0.139)$ whereas fruit girth showed significant positive correlation with fruit weight (0.856) and it has shown significant negative correlation with days to fifty percent flowering (-0.453). Plant height showed significant positive correlation with number of fruits (0.412) whereas significant negative correlation was found with fruit girth $(-0.361)$ and fruit weight (-0.312). Similar results were reported by Bisht et al., (2010), Sharma et al., (2010), Badgujar and More (2004) and Gulam ud din et al., (2006), Eifediyi and Remison (2009), Shaw et al., (2000), Dijkhuizen and Staub (2002), Singh et al., (2002), Das et al., (2003), Verma (2003), Kumaret al., (2008), Munshi et al., (2007), Hanchinamani et al., (2008), Kumar et al., (2013), Soleimani et al., (2009), Singh et al., (2002). Positive correlation makes 
simultaneous improvement in two or more attributes possible, whereas, negative association indicates the need to compromise between desirable characters. So, when the breeder applies selection for a particular character, not only it improves that trait, but also those characters provide a reliable measure of genetic association between them, which is useful in the breeding programmes.

The path analysis reveals, whether the association of the component characters with yield is due to their direct effect on yield, or is a consequence of their indirect effect via some other trait(s). The direct and indirect effects of yield components on marketable yield are presented in Table 5. In the present study, days to first female flower showed negative direct effect (-0.3557) on fruit yield per plant (-0.379). However, its strong positive association with fruit yield was mainly of its positive indirect effect through nodal position of first female flower (0.5077) and fruit weight (0.4039). Nodal position of first female flower showed positive direct effect (0.7253) on fruit yield per plant (0.716). However, its strong positive association with fruit yield was mainly of its positive indirect effect through fruit weight (0.4072) whereas its strong negative association with fruit yield was via days to first female flower (-0.2489), number of fruits $(-1.5148)$ and fruit length $(-0.1028)$. Days to fifty percent flowering showed positive direct effect (0.1019) on fruit yield per plant (0.707). However, its strong positive association with fruit yield was mainly of its positive indirect effect through nodal position of first female flower (0.3698) and fruit girth (0.3715) whereas its strong negative association with fruit yield was via number of fruits (-0.9427), fruit weight $(-0.4493)$ and days to first female flower (-0.1873).Number of fruits per plant showed positive direct effect (0.8176) on fruit yield per plant (0.825). However, its strong positive association with fruit yield was mainly of its positive indirect effect through days to first female flower (0.1732) and fruit girth (0.1339) whereas its strong negative association with fruit yield was via nodal position of first female flower (-0.6045) and fruit weight (-0.6048). Fruit weight showed positive direct effect $(0.6198)$ on fruit yield per plant (0.186). However, its strong positive association with fruit yield was due its positive indirect effect through nodal position of first female flower (0.1823) whereas its strong negative association with fruit yield was via fruit girth $(-0.7020)$,number of fruits per plant (-0.6786) and fruit length (0.1848 ).Fruit length showed negative direct effect (-0.3535) on fruit yield per plant (0.218). However, its strong positive association with fruit yield was mainly of its positive indirect effect through fruit weight $(0.8468)$ and nodal position of first female flower (0.2109) and whereas its negative association with fruit yield was via number of fruits per plant $(-0.2536)$ and fruit girth (0.1270 ) and days to first female flower ($0.1084)$.Fruit girth showed negative direct effect $(-0.8021)$ on fruit yield per plant (0.278). However, its strong positive association with fruit yield was due to its positive indirect effect through fruit weight (0.3868) whereas its negative association with fruit yield was via number of fruits per plant $(-0.2968)$. Plant height showed negative direct effect (-0.2119) on fruit yield per plant (0.303). However, its strong positive association with fruit yield was due to its positive indirect effect through number of fruits per plant (0.7494) and fruit girth $(0.2964)$ whereas its negative association with fruit yield was via fruit weight $(-0.5052)$. The path coefficient analysis revealed that maximum positive direct effects towards fruit yield per plant was contributed by days to fifty percent flowering, number of fruits per plant and fruit weight were the most influencing factors. Thus, these characters 
deserve greater weightage during selection for yield. The direct selection in these traits would be rewarding for improvement in the fruit yield per plant. These are agreement with earlier reports given by Verma (2003), Kumaret al., (2008), Munshi et al., (2007), Hanchinamani et al., (2008), Soleimani et al., (2009), Singh et al., (2002), Rakhi and Rajmony (2005), Kumar et al., (2013) and Singh (2007).

However in the present study the gynoecious parthenocarpic hybrids namely Vally Star, Multi Star, Silyon and Pune collection were the best with respect to earliness as well as maximum yield. These genotypes having quality parameters (Table 1) like good taste, absence of spines (smooth fruit surface), there is no no splitting or hallow and absence of ribs or warts. Hence, these hybrids on commercial scale in naturally ventilated polyhouse can improve productivity and generate good income to the growers. These technologies are highly suitable for increasing the socioeconomic status of small farmers through high profitability.

In conclusions, the characters which showing high PCV with equally high GCV, high heritability coupled with high genetic advance which indicates maximum variability is existing in the genotypes for these characters and offers good scope for improvement by simple selection through these characters. Correlation studies revealed that at both phenotypic and genotypic level highly significant and positive association of fruit yield per plant with number of fruits per plant and negative association with days to first female flower, nodal position of first female flower and days to fifty percent flowering indicating the possibility of simultaneous selection for these traits to improve the fruit yield. maximum positive direct effects towards fruit yield per plant was contributed by days to fifty percent flowering, number of fruits per plant and fruit weight were the most influencing factors. The hybrids namely Vally Star, Multi Star, Silyon and Pune collection were the best with respect to earliness, superior quality as well as maximum yield.

\section{References}

Al-Jibouri, H. A., Miller, P. A. and Robinson, H. V. 1958. Genotypic and environmental variances and covariances in an upland cotton cross of interspecific origin. Agronomy Journal, 50: 633-636.

Anonymous, 2013-14. Indian Horticulture Database-2012. National Horticulture Board, Ministry of Agriculture, Government of India.

Badgujar, C.D., More, T.A. 2004. Off season performance of selected tropical gynoecious cucumber hybrids grown under different regimes. South Indian Hort., 52(1-6): 97-103.

Bisht, B., Singh, M. P., Srivastava, B.K., Singh, Y.V., and Singh, P. K. 2010. Evaluation of open-pollinated varieties and hybrids of cucumber for off-season production under naturally ventilated polyhouse. Indian Journal of Horticulture., 67(2): 202-5.

Burton, G.W. and De Vane, D.H. 1952. Estimating heritability in tall fescue (Festuca arundiacea) from replicated clonal material. Agron. J. 54: 478-81.

Burton, G.W., and Devane, R.W. 1953. Estimating heritability in tall foscue (Festuca arubdinaces) from replicated clonal material. Agron. J., 45: 478-481.

Cardoso AII, Silva NDA. 2003. Evaluation of "Japanese" cucumber hybrids under protected cultivation in two sowing dates. Horticultura Brasileira 21(2): 171-176.

Das, S., Maurya, K. R., and Choudhary, D. N. 2003. Heritability studies in cucumber. Journal of Applied Biology., 13(1\&2): 
54-7.

De Candolle, A., 1882. Origine des plantescultive. Germes Bailliere, Paris. $377 \mathrm{p}$.

Devmore, J. P., Dhonukshe, B. L., Thaware, B.. L, Bendale, V.W., Jadhav, B.B., and Thprat, T. N. 2010. Genetic variability and heritability studies in bitter gourd (Momordica charantia L.). Journal of Maharashtra Agricultural Universities., 35(1): 163-5.

Dewey, D.H. and Lu, K.H. 1959.A correlation and path analysis of components of crested wheat grass production. Agron. J., 51: 515-518.

Dijkhuizen, A. and Staub, J.E. 2002. QTL conditioning yield and fruit quality traits in cucumber (Cucumissativus L.): effects of environment and genetic background. Journal of New Seeds, 4: 130.

Eifediyi, K. Remison, S.U. 2009. Effect of time of planting on the growth and yield of five varieties of cucumber (Cucumis sativus L.). Report and Opinion 1(5): 81-90.

Gulam-Ud-Din, Ahmed, N. Narayan, R. Nazir, G. and Hussain, K. 2006. Variability studies in cucumber. Haryana J, Hortl Sci., 35(3, 4): 297298.

Hanchinamani, C. N., Patil, M. G., Dharmatti, P. R., and Mokashi, A. N. 2008. Studies on variability in cucumber (Cucumis sativus L.). Crop Research, 36(1\&3): 273-6.

Johnson, H. W., Robinson, H. F. and Comstock, R. E.1955. Estimates of genetics and environmenta1 variability in soybeans. Agron. J., 47: 314-318.

Kumar, A., Kumar, S., and Pal, A. K. 2008. Genetic variability and characters association for fruit yield and yield traits in cucumber. Indian Journal of Horticulture., 65(4): 423-8.

Kumar, S., Kumar D., Kumar, R., Thakur, K.
S., Dogra, B. S. 2013. Estimation of genetic variability and divergence for fruit yield and quality traits in cucumber (Cucumis sativus L.) in North-Western Himalays. Universal Journal of Plant Science, 1(2): 27-36.

Munshi, A. D., Panda, B., Behera, T. K., Kumar, R., Bisht, I.S., and Behera, T. K. 2007. Genetic variability in Cucumis sativus var. Hardwickii R. germplasm. Cucurbit Genetics Cooperative Report. 30: 5-10.

Rakhi, R., and Rajamony, L. 2005. Variability, heritability and genetic advance in landraces of culinary melon (Cucumis melo L.). Journal of Tropical Agriculture., 43(1-2): 79-82.

Sharma, A., Kaushik, R.A., Sarolia, D.K., Sharma, R.P. 2010. Response to cultivars, plant geometry and methods of fertilizer application on parthenocarpic cucumber (Cucumis sativus L.) under zero energy polyhouse condition during rainy season. Veg Sci., 37(2): 184-186.

Shaw, N.L., Cantliffe, D.J., Rodriguez, J.C., Taylor, S., Spencer, D.M. 2000. Beit Alpha Cucumber - an exciting new greenhouse crop. Proc Fla State Hortl Soc., 113: 247-253.

Singh, M., 2007. 'Variability studies in some lines of cucumber (Cucumis sativus L.)'. M Sc. thesis, Department of Vegetable Science, Dr Y S Parmar University of Horticulture and Forestry, Nauni, Solan, HP.

Singh, R. V., Verma, T. S., and Thakur. P.C. 2002. Characters association in cucumber. Haryana Journal of Horticultural Sciences. 31(1\&2): 91-3.

Soleimani, A., Ahmadikhah, A., Soleimani, S. 2009. Performance of different greenhouse cucumber cultivars (Cucumis sativus L.) in southern Iran. African J. Biotechnol., 8(17): 40774083. 
Verma, S., 2003. 'Genetic variability and correlation studies in cucumber (Cucumis sativus L.)'. M Sc. thesis, Department of Vegetable Science, Dr Y S Parmar University of Horticulture and Forestry, Nauni, Solan, HP.

Vijayakumari, P. More, T.A., Seshadri, V.S. 1991. Evaluation of gynoecious F1 hybrids for horticultural characters in cucumber. Veg Sci., 18(2): 167-176. Wright, S., 1921, Correlation of caustion. J. Agril. Res., 20: 202-209.

Yogesh, C., Yadav, S. K, Brijpal, B., and Dixit, S. K. 2009. Genetic variability, heritability and genetic advance for some traits in cucumber. Indian Journal of Horticulture 66(4): 488-91.

\section{How to cite this article:}

Gangadhara, K., Raj Kumar, R. Selvakumar, V.V. Apparao and Yadav, L.P. 2019. Evaluation of Cucumber Hybrids/Lines for Yield and Quality under Polyhouse. Int.J.Curr.Microbiol.App.Sci. 8(06): 1652-1661. doi: https://doi.org/10.20546/ijcmas.2019.806.197 